\section{First Australians}

\author{
John Launer
}

I recently returned from my first visit to Australia. I spent 2 weeks in New South Wales and Canberra, running workshops in clinical supervision. Inevitably, I noted some differences between the Australian health service and the British one, but there was far more that was very familiar. The overall ethos, attitudes and styles of practice seem more like British ones than any other country I have ever visited. However, there was one custom quite different from anything I have seen elsewhere. It certainly challenged any remaining stereotypes I may have held about Australians. At almost every event I attended, the person conducting the welcome and introductions began by acknowledging the local aboriginal nation on whose traditional territory the event was being held, and paying respect to their elders past and present. The custom is observed widely at public events, and in the medical world it is followed meticulously and with conviction.

I knew a little of Australian history before my trip but learned a great deal more while I was there. People of European ancestry have only dominated the Australian continent for around 10 generations. For possibly 40000 years or 1600 generations before that, the land was occupied, owned and indeed cultivated by hundreds of indigenous nations and language groups that were more diverse than in Europe and largely lived in a state of peaceable coexistence with each other. They had a rich cultural and artistic heritage, with an emphasis on ancestors, dancing and singing, and unique skills in areas such as navigation in the desert and forest regeneration. The arrival of Dutch, French and English explorers in the 18th century was one of the most sudden and catastrophic acts of colonisation in the history of the world. It introduced epidemic disease, alcoholism, warfare, displacement, abduction, rape, cultural destruction and genocide on an unprecedented scale, wiping out some whole aboriginal nations and subjugating all the others. Most of this horrific history

Correspondence to Dr John Launer, Faculty Development, Shared Services, Health Education, Stewart House, 32 Russell Square, London WC1B 5DN, UK: john.launer@southlondon.hee.nhs.uk was suppressed or denied by European Australians until the late twentieth century. This finally came to an end with the introduction of an annual National Sorry Day in 1998 to commemorate two centuries of mistreatment of aboriginals. This gesture of remorse was followed by an equally important one in 2008 when Kevin Rudd became the first Australian prime minister to apologise for the forcible and systematic separation of thousands of aboriginal children from their families in an attempt to turn them into 'white Australians'.

\section{PASSIONATE COMMITMENT}

During my visit, I had the opportunity of meeting a number of people whose ancestors had been 'first Australians'. I saw an aboriginal health centre in western Sydney where the professor of general practice who conducted me around was careful to observe the local courtesy of introducing me to the clinic manager-himself an aboriginal-and asking his consent for welcoming me to the premises. In our spare time, my wife and I had several other occasions for learning about indigenous culture, including a visit to the Rocks Discovery Museum in Sydney and going on their aboriginal heritage tour. Without forming any illusions about the irreparable wounds that the European invasion caused, or the great distance that still needs to be travelled in terms of reparation, we were profoundly struck by the warmth and resilience of the aboriginal people we met, and by the passionate commitment of many newer Australians to make amends for the crimes of their recent ancestors.

Since returning from Australia, I have read three seminal books about the aboriginal genocides. All were recommended by people there who wanted me to understand how the country reached a desire for healing past injuries through reconciliation. One is a documentary history by Inga Clendinnen, charting the years when initial curiosity by the British invaders turned rapidly into acts of aggression. ${ }^{1}$ Another is The secret river, a prizewinning novel by Kate Grenville, recreating the story of how British convicts, deported for petty crimes, turned into casual murderers of the local inhabitants. ${ }^{2}$ Finally, there is a travelogue entitled Terra Nullius-after the English legal fiction that declared Australia unoccupied and belonging to no-one. It describes some of the sites of aboriginal suffering, interspersed with a commentary on what this means and what might be done in response. ${ }^{3}$ In different ways, each of these books makes the same point: hatred of other people begins by denying the abuses people have undergone. It ends by accepting responsibility on behalf of your own kin for causing those abuses. As Sven Lindqvist, the author of Terra Nullius, states very simply: if you know you have benefitted from a crime, however remote in time or place, it imposes on you a duty of reparation.

\section{MARKED CONTRAST}

It has been impossible to learn all of this without also becoming aware of the marked contrast with prevailing attitudes to colonial history in Britain. In the UK, there seems a vague and general acceptance that occupation of other continents until the mid-twentieth century by people from our small northern island may not have been an entirely benign experience for their native inhabitants. Yet, by comparison with Australia, there seems little awareness of the scale and nature of abuses carried out overseas in the name of our governments. There is certainly no strong collective recognition that it was people from Britain that first began systematic massacres in Australia-not to mention North America, South Africa and elsewhere-or that we should join with the modern-day leaders of these places nowadays in acknowledging this fact. No prime minister has ever apologised for the slave trade, which devastated the lives of many millions of Africans and their families. The city of Liverpool now has an International Slavery Museum, but London, to its shame, does not, even though a great deal of its wealth was built on that trade, and on slave labour in British-owned plantations. There is no National Sorry Day for the Irish famines. Although Holocaust Memorial Day is observed in the UK-something I appreciate as the child of Jewish refugees-few Britons were complicit in the extermination of European Jews. Other imperial atrocities might be commemorated just as fittingly, if not more so.

What would the purpose of such commemoration be? If the Australian example is anything to go by, it might serve as a reminder that the effects of such barbaric acts do not go away, nor do the nations and peoples who suffer from them feel that they have. The sentiment 'it's all history now' is easier for the descendants 
of perpetrators express than it is for people whose ancestors were victims, and who in many cases continue to suffer the social, economic and psychological disadvantages of their ancestry. For many of the doctors, nurses and allied health professionals I met in New South Wales and Canberra, the formal statements at training events seemed to underwrite a personal, moral commitment of the kind that Lindquist invites. A public confession by politicians of historical wrongs done by Great Britain might lead to a similar commitment.

If that never happens (as seems likely), the individual commitment is still possible. Many of our own patients-or their immediate forebears-have been through experiences of colonialism that have damaged or disadvantaged them in multiple ways. The same is true, of course, of many of our colleagues in the health service, whose careers here may be inextricably connected with the complex long-term impact of the British Empire. Understanding the negative side of that imperial history may be essential for understanding the vast number of people still affected by it, for working with them, for looking after them properly, and for appreciating their own perspective on Britain.
Competing interests None.

Provenance and peer review Commissioned; internally peer reviewed.

To cite Launer J. Postgrad Med J 2013;89:549-550.

Postgrad Med J 2013;89:549-550.

doi:10.1136/postgradmedj-2013-132292

\section{REFERENCES}

1 Clendinnen I. Dancing with strangers: Europeans and Australians at first contact. Cambridge: Cambridge University Press, 2005.

2 Grenville K. The secret river. New York: Canongate, 2005.

3 Lindqvist S. Terra Nullius: a journey through no one's land. New York: New Press, 2007. 